\title{
Dream and Doubt: Skepticism in Shakespeare's Hamlet and Calderón's La vida es sueño
}

The resurgence of ancient skepticism in the sixteenth and seventeenth centuries represents one of the critically formative phenomena of the cultural history of the early modern period. This essay seeks to explore how both William Shakespeare's Tragedy of Hamlet, Prince of Denmark, written around the year 1600, as well as Pedro Calderón de la Barca's most famous comedia, La vida es sueño [Life Is a Dream], published in 1636, have incorporated elements deriving from this influential philosophical discourse, as well as the related epistemological and ethical questions regarding contemporary discussions of skepticism, or, in other words, why and how these plays dramatise the fundamental epistemological question of skepticism in early modern Europe. ${ }^{1} \mathrm{~A}$ further emphasis of the analysis will be on

1 For a comparative study on the two dramas that focuses on the aspect of skepticism, see already Joachim Küpper, "Hamlet, by Shakespeare, and La vida es sueño, by Calderón, or the Problem of Scepticism," Germanisch-Romanische Monatsschrift 58 (2008), pp. 367-399; see, furthermore, Küpper, “La vida es sueño: 'Aufhebung' des Skeptizismus, Recusatio der Moderne,” in: Küpper and Friedrich Wolfzettel, edd., Diskurse des Barock: Dezentrierte oder rezentrierte Welt? (München: Fink, 2000), pp. 383-426; for Hamlet in particular see Verena Olejniczak Lobsien, Skeptische Phantasie: Eine andere Geschichte der frühneuzeitlichen Literatur (München: Fink, 1999), esp. pp. 102-126. With respect to skepticism in Shakespeare's famous tragedy, see, moreover, among others, Millicent Bell, Shakespeare's Tragic Skepticism (New Haven, CN/ London: Yale University Press, 2002), pp. 29-79; Graham Bradshaw, Shakespeare's Scepticism (Brighton: Harvester Press, 1987), pp. 95-125; Stanley Cavell, Disowning Knowledge in Six Plays of Shakespeare (Cambridge/New York, NY: Cambridge University Press, 1987), pp. 179-192; John D. Cox, "Shakespeare and the French Epistemologists," Cithara 45 (2006), pp. 23-45; Aaron Landau, “'Let me not burst in ignorance': Skepticism and Anxiety in Hamlet," English Studies 82 (2001), pp. 218-230; Christoph Menke, “Tragödie und Skeptizismus: Zu Hamlet,” Deutsche Vierteljahrsschrift für Literaturwissenschaft und Geistesgeschichte 75 (2001), pp. 561-486. Regarding studies on the aspect of skepticism in La vida es sueño, see, in addition, among others, Anthony J. Cascardi, The Limits of Illusion: A Critical Study of Calderón (Cambridge/New York, NY: Cambridge University Press, 1984), pp. 11-23; William Egginton, "Psychoanalysis and the Comedia: Skepticism and the Paternal Function in La vida es sueño," Bulletin of the Comediantes 52 (2000), pp. 97-122; Everett W. Hesse, “The Role of Deception in La vida es sueño," in: Bruno M. Damiani, ed., Renaissance and Golden Age Essays in Honor of D. W. McPheeters (Potomac, MD: Scripta Humanistica, 1986), pp. 120-129; Andrés Lema-Hincapié, “¿Existir en sueño o en vigilia? Las respuestas de Calderón y Descartes,” Daimon 34 (2005), pp. 53-68; Bárbara Mujica, “Calderón’s La vida es sueño and the Skeptic Revival," in: Arturo Pérez-Pisonero and Ana Semiday, edd., 
aspects of the topic of dream, present in both dramas, which will be considered in connection with the elements of skepticism thematised in the texts. Before entering into the discussion of the plays-on the basis of some central scenes-, however, I shall first briefly outline the philosophical and historical frame of reference.

In The History of Scepticism, the historian of philosophy Richard Popkin emphasised an extensive skeptical, i.e. "Pyrrhonian[,] crisis" ("crise pyrrhonienne") pervading early modern Europe, in particular at the beginning of the seventeenth century. ${ }^{2}$ In attempting to overcome this crisis, that is, in confronting skepticism, important impulses emerged that became decisive for the configuration of modernity. At the latest, the publication in 1562 of the first Latin translation of the basic systematic exposition of Pyrrhonian skepticism-named after the legendary figure Pyrrho of Elis (c. 365-275 BCE) - written by the Greek physician and philosopher Sextus Empiricus in the second century CE ensured a wide dissemination and reception of this philosophical current. ${ }^{4}$ The central elements and terms of

Texto y espectáculo: Nuevas dimensiones críticas de la 'comedia' (New Brunswick, NJ/El Paso: SLUSA, 1990), pp. 23-32; Henry W. Sullivan, “Tam clara et evidens: 'Clear and Distinct Ideas' in Calderón, Descartes, and Francisco Suárez, S. J.,” in: Alva V. Ebersole, ed., Perspectivas de la comedia, 2 vols. (Valencia: Estudios de Hispanófila, 1978), vol. 2, pp. 127-136.

2 See Richard H. Popkin, The History of Scepticism: From Savonarola to Bayle, $3^{\text {rd }}$ ed. (Oxford/ New York, NY: Oxford University Press, 2003), pp. 3-98, esp. pp. 3-43.

3 Of this Greek philosopher, who participated in the campaigns of Alexander the Great into India, mainly anecdotal information has been passed down; as we can read in Diogenes Laertius' account of Pyrrho: "He denied that anything was honourable or dishonourable, just or unjust. And so, universally, he held that there is nothing really existent, but custom and convention govern human action; for no single thing is in itself any more this than that. He led a life consistent with this doctrine, going out of his way for nothing, taking no precaution, but facing all risks as they came, whether carts, precipices, dogs or what not, and, generally, leaving nothing to the arbitrament of the senses; but he was kept out of harm's way by his friends who [...] used to follow close after him." (Diogenes Laertius, [Vitae et sententiae philosophorum, Book 9, chap. 11, 61-69] Lives of Eminent Philosophers: Greek-English, trans. Robert Drew Hicks, 2 vols. [London: Heinemann; New York, NY: Putnam's Sons, 1925], pp. 474-483, p. 475 [62])

4 The 1562 edition, published by Henri Estienne, was followed by Gentian Hervet's Latin publication of Sextus' complete works in 1569. The Greek original of the Pyrrhoneioi Hypotyposeis was published in 1621, and at the end of the sixteenth century parts of an English version appeared, the first translation into a modern vernacular language. (See Popkin, History of Scepticism, pp. 18 f.) But already in the Middle Ages Sextus' writings were known. In fifteenth-century Italy, Greek manuscripts circulated among humanistic intellectuals. (See, for instance, Luciano Floridi, Sextus Empiricus: The Transmission and Recovery of Pyrrhonism [Oxford/New York, NY: Oxford University Press, 2002], pp. 13-25, regarding the transmission in the Middle Ages; also pp. 25-51, regarding the reception in the Renaissance, and esp. pp. 27-35, regarding the rediscovery by the Italian humanists). Popkin writes: "From the mid-fifteenth century onward, with the discovery of 
classical skeptical thinking set forth in Sextus Empiricus' Outlines of Pyrrhonism, are as follows: isosthenia, the equally balanced co-presence of opposing arguments; epoché, the suspension of judgement that follows from isosthenia, that is, from the undecidability, or the impossibility of recognising the truth of a statement; and ataraxia, the tranquil state of mind that, according to the skeptics, can be attained fortuitously by practising epoche. ${ }^{5}$ The skeptical argumentation is characterised by assuming consistent relativity; it thus continually casts doubt on any claim of absoluteness. The skeptics' argumentative repertoire is provided by the famous skeptical tropoi, the so-called "tropes" or "modes of suspension of judgement." These are argumentative schemes designed to demonstrate relativity. In most cases, they emphasise that sensory perception cannot provide a basis for certain knowledge. ${ }^{6}$ In anticipation of what is to come later in my readings of

manuscripts of Sextus' writings, there is a revival of interest and concern with ancient skepticism and with the application of its views to the problems of the day." (History of Scepticism, p. xx). For a study that focuses on the aspect of skepticism in medieval times, see Dominik Perler, Zweifel und Gewißheit: Skeptische Debatten im Mittelalter, $2^{\text {nd }}$ ed. (Frankfurt a.M.: Klostermann, 2012). In addition to Popkin's study, see, for the influence of skepticism in sixteenth-century Spain, the account given in Maureen Ihrie, Skepticism in Cervantes (London: Tamesis, 1982), pp. 19-29, and for the reception in England, see William M. Hamlin, Tragedy and Scepticism in Shakespeare's England (Basingstoke/New York, NY: Palgrave Macmillan, 2005), pp. 29-115.

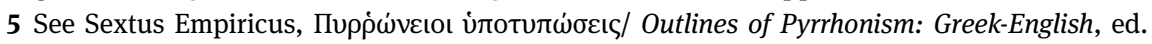
and trans. Robert Gregg Bury, in: Sextus Empiricus, ed. and trans. R. G. Bury, 4 vols. (London: W. Heinemann; Cambridge, MA: Harvard University Press, 1933-1949), vol. 1, Book 1, 1-12, pp. 2-9, and Book 1, 25-29, pp. 18-21. See, for instance: "Scepticism is an ability, or mental attitude, which opposes appearances to judgements in any way whatsoever, with the result that,

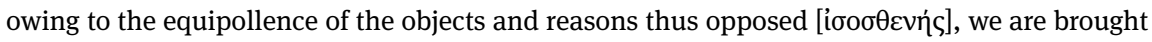
firstly to a state of mental suspense [غ̇лохи́] and next to a state of 'unperturbedness' or quietude

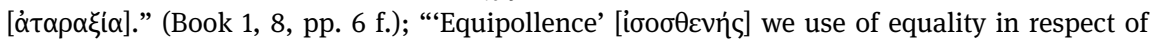
probability and improbability, to indicate that no one of the conflicting judgements takes precedence over any other as being more probable. 'Suspens[ion of judgement]' [غ̇лoxи́] is a state of

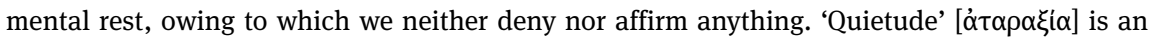
untroubled and tranquil condition of soul.” (Book 1, 10, pp. 6-9); “[...] [T] hey [the skeptics] sus-

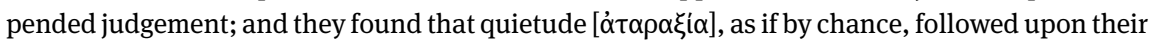
suspense [غ̇лохи́], even as a shadow follows its substance.” (Book 1, 29, pp. 20 f.) All references in this essay to the Outlines of Pyrrhonism are from Bury's bilingual edition. The following more recent English editions of the Hypotyposeis, however, are to be noted and have been consulted as well: Sextus Empiricus, Outlines of Scepticism, edd. and trans. Julia Annas and Jonathan Barnes (Cambridge/New York, NY: Cambridge University Press, 2000); Sextus Empiricus, The Skeptic Way: Sextus Empiricus's Outlines of Pyrrhonism, ed. and trans. Benson Mates (Oxford/New York, NY: Oxford University Press, 1996).

6 See Sextus Empiricus, Outlines of Pyrrhonism, Book 1, 36-163, pp. 24-93, for the ten "tropes of epoché" attributed to Aenesidemus (first century BCE). As Sextus summarises at the beginning: "They are these: the first, based on the variety in animals; the second, on the differences 
the plays, I shall quote from the fourth of the ten tropes listed in Sextus' Outlines of Pyrrhonism, which states that, because the results of sensory perceptions vary according to different conditions, i.e. according to the mental or physical state of the perceiver at the moment of perception-such as sleeping or waking, drunkenness or sobriety, motion or rest, young or old age-, making a reliable judgement about the "reality status" of the perceived is impossible. The following applies with respect to the waking state, sleeping and dreaming:

Sleeping and waking [...] give rise to different impressions, since we do not imagine when awake what we imagine in sleep, nor when asleep what we imagine when awake; so that the existence or non-existence of our impressions is not absolute but relative, being in relation to our sleeping or waking condition. Probably, then, in dreams we see things which to our waking state are unreal, although not wholly unreal; for they exist in our dreams, just as waking realities exist, although non-existent in dreams. ${ }^{7}$

The dream argument would become centrally important in René Descartes' (1596-1650) well-known use of and attempt to overcome skepticism ${ }^{8}$-an aspect I will also come back to in the discussion of the dramas.

The core argument of Pyrrhonism is doubt concerning the reliability of sense perception. The skeptical assumption that our perception is relative opposes Aristotelian epistemology, which claims that all knowledge begins with perception and that we are able, by means of the senses governed by reason, to arrive at a true, objective view of the world. From a skeptical point of view, no reliable statements can be made about reality: the world does not actually have to be as it

in human beings; the third, on the different structures of the organs of sense; the fourth, on the circumstantial conditions; the fifth, on positions and intervals and locations; the sixth, on intermixtures; the seventh, on the quantities and formations of the underlying objects; the eighth, on the fact of relativity; the ninth, on the frequency or rarity of occurrence; the tenth, on the disciples and customs and laws, the legendary beliefs and the dogmatic convictions." (Book 1, 36 f., p. 25) In addition, Sextus gives the five modes of suspension of judgement attributed to Agrippa (first century CE), "on disagreement," “on regress ad infinitum,” "on relativity,” “on hypothesis," and "on circular reasoning” (Book 1, 164-177, pp. 94-101), another list of two tropes (Book 1, 178 f., pp. 100-103) and a catalogue of "skeptic expressions" [ $\varphi \omega v \alpha i$ ] (Book 1, 187-209, pp. 106-125), all these providing argumentative instruments to set up equipollence.

7 Book 1, 104, p. 63; on trope 4 on the whole, see Book 1, 100-117, pp. 58-69.

8 See René Descartes, Meditationes de prima philosophia [1641], in: Euvres de Descartes, edd. Charles Adam and Paul Tannery, 13 vols. (Paris: Cerf, 1897-1913), vol. 7, esp. Meditatio 1, pp. 17-23, esp. pp. 19 f.; Descartes, Meditations on First Philosophy, in: The Philosophical Writings of Descartes, trans. John Cottingham, Robert Stoothoff and Dugald Murdoch, 3 vols. (Cambridge/New York, NY: Cambridge University Press, 1984-1991), vol. 2, pp. 1-62, First Meditation, pp. 12-15, esp. p. 13. 
appears to us. ${ }^{9}$ The questions and problems posed by skepticism are not only concerned with the field of knowledge but also extend to ethics and praxis. From the perspective of the skeptics, the state of not knowing is in no way a shortcoming; on the contrary, it is brought about deliberately and encountered by refraining from judgement with serenity. The central question of how one is to behave in the face of uncertainty or how a skeptical attitude is to be integrated into practical life is answered by the Pyrrhonists-whose goal is to lead a carefree, completely undogmatic life-as follows: one must adhere to the world as one finds it; to what is accepted in the community in which one finds oneself living. With respect to undertaking necessary action, one must orient oneself by everyday experience and by following tradition and custom. ${ }^{10}$

The revival of Pyrrhonian skepticism in the early modern period is not only situated within a humanistic interest in ancient literature and philosophy, but occurred in particular against the backdrop of a period marked by massive changes, the loss of previous certainties and new epistemological challenges. Notably, the discovery of new continents beginning in 1492 cast doubt on traditional categories explaining the world. One was faced (from a European perspective) with previously unknown territories not mentioned in the Bible ${ }^{11}$ and

9 See Sextus Empiricus, Outlines of Pyrrhonism, Book 1, 18-22, pp. 12-17.

10 See Book 1, 17, pp. 12 f.; Book 1, 22-24, pp. 16 f.; Book 1, 26-30, pp. 18-21; Book 1, 226, pp. 138 f. The second tradition of ancient skepticism should also be mentioned, known as "Academic skepticism," which was formulated and developed in the Platonic Academy from the third to the first century BCE. The significant distinction between the two ancient forms of skepticism is that the skepticism of the Academics is universal and absolute-the knowledge of truth is considered in principle impossible-, while for the Pyrrhonians, however, it is universal and relative. Thus, according to Sextus, the adherents of Academic skepticism are not perceived as "skeptics," but as "negative dogmatists." According to Popkin, this distinction was also adapted in the context of the reception of skepticism in the early modern age when, in the sixteenth and seventeenth centuries the terms "skeptic" and "Pyrrhonian" were used synonymously by most contemporaries. A momentous modification (also in terms of its reception) that Academic skepticism developed from a principled rejection of truth and certainty and from the concomitant assumption that even deception is in principle not to be excluded, was the substitution of the certainty criterion

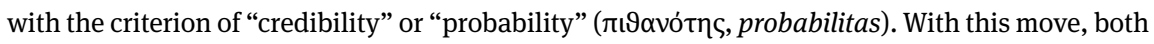
"judgements" about the world and practical action were oriented according to probabilities. The distinction of ideas by degrees of credibility and a detailed examination of their subject allow to a certain extent a provisional "understanding" of reality, only when the verified is credible or likely as opposed to true rather than false. This holds a thoroughly constructive potential in terms of scientific conceptualisations. (See the explanations given in the Outlines of Pyrrhonism on the differences between the skeptics and the Academic philosophy: Book 1, 220-235, pp. 132-145, esp. Book 1, 226-231, pp. 138-143; see Popkin, History of Scepticism, pp. xvii f. and p. xx).

11 Regarding this aspect, see Küpper, "The Traditional Cosmos and the New World," MLN 118 (2003), pp. 363-397. See also already Küpper, “La vida es sueño,” p. 416, for pointing to 
with inhabitants of this "new world" who had unheard-of cultures, knowledge and belief systems. The discovery of America, the circumnavigation of the globe by Magellan (1519-1522) and the definitive end of the Ptolemaic worldview later brought about by the Copernican hypothesis, advanced in the work of Galileo and completed by Kepler's findings, namely, the proof that the earth was a sphere and not at the centre of the universe meant that doubts about the reliability of sense perception-and thus Aristotelian epistemology-, the main argument of skepticism, gained in virulence. In the area of faith, through the Reformation's questioning of the status of the church and the criterion of tradition, the sole valid authority for truth was shaken. Given an emerging pluralism in the fields of science, philosophy and religion, the arguments of the skeptics appeared to be a mode of addressing the uncertainty of one's own time, an uncertainty centred on the reliability of sensory perception.

This applies not only to the realm of philosophy and religion. The reception of classical Pyrrhonism can be understood as a phenomenon extending far beyond philosophy into almost all discourses, affecting the whole of Europe and ubiquitous in early modern culture. As I will try to show in the following pages, looking first at Hamlet and then at La vida es sueño, the challenges generated by skepticism in the intellectual debates of the seventeenth century also concerned the drama of the time and triggered different ways of confronting and "answering" them.

The Hamlet source material derives from Norse mythology and was recorded in writing in the Historiae Danicae of Saxo Grammaticus at the end of the twelfth century. However, it is the expanded version of the story-expanded in particular through moralising commentaries-in François de Belleforest's popular Histoires tragiques (1559-1582) that is generally regarded as one of Shakespeare's immediate sources. ${ }^{12}$ Although constitutive elements of the plot (fratricide, "incestuous marriage," feigned madness and execution of a long-delayed revenge) are present, there is no ghost. Fengon-the equivalent character to

the significance of the discoveries in the context of the reception of skepticism; see in this regard also Popkin, History of Scepticism, p. 98.

12 It is the third histoire of the fifth volume, published for the first time in 1570, of the seven-volume collection of "tragic stories," which Belleforest wrote between 1559 and 1582, initially as a continuation of the translation and adaptation of Bandello's Novelle begun by Pierre Boaistuau and published in 1559 under the title Histoires tragiques. For the sources of Hamlet, see Harold Jenkins, “Introduction,” in: William Shakespeare, Hamlet, ed. Harold Jenkins, The Arden Shakespeare, $2^{\text {nd }}$ Series (London: Thomson Learning, 2005), pp. 1-159, pp. 82-112, esp. pp. 85-89 (Saxo Grammaticus), pp. 89-96 (Belleforest), pp. 82-85 and pp. 97-101 (Ur-Hamlet and The Spanish Tragedy). 
Shakespeare's Claudius-murders Amleth's father in public; consequently, there is no doubt as to the identity of the murderer. ${ }^{13}$ In Hamlet, however, the protagonist, having returned to the Danish court of Elsinore from his place of study in Wittenberg because of his father's sudden death, first and only learns of the murder from the ghost: “GHOST: 'Tis given out that, sleeping in my orchard, / A serpent stung me-so the whole ear of Denmark / Is by a forged process of my death / Rankly abus'd-but know, thou noble youth, / The serpent that did sting thy father's life / Now wears his crown."14

Ghost figures were by no means uncommon on the stage of the time. A significant influence came from the reception of Seneca's tragedies in the sixteenth century. ${ }^{15}$ As is well known, Thomas Kyd's The Spanish Tragedy (printed in 1592) also contains the element of the ghost figure and in reports on performances of the so-called Ur-Hamlet, the appearance of a ghost is highlighted as well. In numerous plays of Shakespeare's oeuvre, there are aspects of the "supernatural," and also specifically in the form of ghosts (consider Richard III or Julius Caesar).

It is not the figure of the ghost itself in Hamlet that is relevant in Shakespeare's modification of the source material, but its problematic reality status; the doubts about the reality of the ghost and of his words are directly connected to the central motif of the play: Hamlet's hesitation over carrying out the revenge called for by the spirit of his father. Thus, two key aspects in the context of the discussion related to skepticism are brought into play: firstly, the field of epistemology, the question of the possibility of identifying what is perceived via the senses as "certain"-this is doubted by the skeptics and represents one of their main arguments; secondly, the area of praxis (which is connected to the former complex of problems), the question of whether and how a specific action is possible when facing uncertainty.

13 See François de Belleforest, Histoires tragiques. Histoire 108 [1604]: “Avec quelle ruse Amleth qui, depuis, fut roi de Danemark, vengea, la mort de son père Horwendille, occis par Fengon son frère et autre occurrence de son histoire," in: Christian Biet, ed., Théâtre de la cruauté et récits

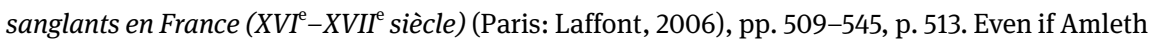
is still a child at the time of the act, the code of honour commits him to avenge the murder of his father as soon as he has reached manhood. His feigned madness serves to gain time and to lull the murderer, who took possession of his victim's throne, empire and wife, into a false sense of security (see p. 515 f.).

14 William Shakespeare, Hamlet, 1.5.35-40. All references to the play are from Shakespeare, Hamlet, ed. Jenkins, and are subsequently given parenthetically in the text.

15 See already Frederic W. Moorman, "The Pre-Shakespearean Ghost," Modern Language Review 1 (1906), pp. 86-95, esp. p. 89 f.; on ghostly apparitions in Elizabethan theatre, see also Stephen Greenblatt, Hamlet in Purgatory (Princeton, NJ/Woodstock: Princeton University Press, 2001), pp. 151-204 (chap. 4 "Staging Ghosts”). 
The question of the ghost's "ontological” status is virulent from the play's outset. In the opening scene of the drama, the sentinels are waiting together with Horatio for his appearance at midnight:

HoRATIO: What, has this thing appear'd again tonight?

BARNARDO: I have seen nothing.

MARCELLUS: Horatio says 'tis but our fantasy,

And will not let belief take hold of him,

Touching this dreaded sight twice seen of us.

Therefore I have entreated him along

With us to watch the minutes of this night,

That if again this apparition come,

He may approve our eyes and speak to it.

HoRATIO: Tush, tush, 'twill not appear.

(1.1.24-33; my italics)

The problem of classifying the perceived continues, as the spirit actually appears twice in the further course of the scene, only to vanish again shortly afterward without responding to the words of Horatio (1.1.43-54, 1.1.128-146). At no point is he clearly identified with the late king; only a similarity is emphasised several times (see 1.1.43-46, 49-53, 61-67, 113). The uncertainty, perceived as threatening, about the cause and significance of the "apparition"16 evokes attempts at interpretation, which draw upon mythical explanations and include the current political and military situation. ${ }^{17}$ There are explicit references to the realm of speculation ("HoR.: So have I heard and do in part believe it." 1.1.170; "MAR.: Some say that [...]" 1.1.163); and the uncertainty about what is seen manifests itself in the irritated exclamations, as the ghost disappears in the mist of dawn: "BAR.: 'Tis here. / HoR.: 'Tis here. / MAR.: 'Tis gone.” (1.1.145-147).

Horatio decides to inform Hamlet about what he believes he has seen; ${ }^{18}$ but even before the ghost is mentioned in their conversation in the second scene of the first act, Hamlet says: "My father-methinks I see my father- / HoR.: Where,

16 See, e.g., "HoR.: [...] It harrows me with fear and wonder.” (1.1.47).

17 It is only a few weeks' time since the sudden and mysterious death of King Hamlet. Denmark is now making evident preparations for war, the cause of which remains unknown to the public (1.1.73-82). Horatio states that, according to rumours, an attack from Norway is imminent; Young Fortinbras is said to intend recapturing the areas that his father had lost in the battle against King Hamlet (1.1.83-110). The ghost is interpreted on the one hand as a "portentous figure" (1.1.112), as an ominous sign of the future of the state (1.1.72), in which parallels are drawn to the mysterious events that supposedly took place before the death of Caesar in ancient Rome (1.1.16-128); on the other hand, it is connected with topoi based on popular beliefs about apparitions (see, e.g., 1.1.139-141, 154-170).

18 "HoR.: This spirit, dumb to us, will speak to him." (1.1.176). 
my lord? HAMLET: In my mind's eye, Horatio.” (1.2.184 f.) This reference to the internal senses, that is, to the realm of the imaginary, of vision and the dreamlike is relevant against the backdrop of Hamlet's "actual" encounters with his father's ghost (in 1.4-5 and 3.4), to the extent that there is no certainty as to whether these encounters have reality status (that is, they are perceived by the outer senses), or whether they too happen only in Hamlet's "mind's eye." The distinction between external and internal sense perception ("fantasy") is frequently thematised in the play, most prominently in Horatio's reaction to the first appearance of the ghost: "BAR.: Is not this something more than fantasy? / [...] / HoR.: Before my God, I might not this believe / Without the sensible and true avouch / of mine own eyes." (1.1.57-61; my italics).

Hamlet is incredulous ("'Tis very strange." 1.2.220) and unsettled ("but this troubles me." 1.2.224) by the report of his friend and the guards and asks detailed questions regarding the appearance of the apparition. ${ }^{19}$ Nevertheless, the scene closes with the statement: "HAM.: My father's spirit-in arms! All is not well. / I doubt some foul play." (1.2.255 f.). ${ }^{20}$ The vague assumption that something is going wrong, that "foul play" is at work, becomes concrete only when Hamlet is "in direct contact" with the ghost, who clearly calls what happened a crime: "Ghosт: I am thy father's spirit, / [...] / If thou didst ever thy dear father love-/ HAM.: O God! / GHOST: Revenge his foul and most unnatural murder. / HAM.: Murder!" (1.5.9-26). The exclamation of Hamlet following the revelation of the murderer (1.5.35-40), “O my prophetic soul! My uncle!” (1.5.41), repeats not only the dimension of inner perception ("in my mind's eye"), but also implies the possibility of a prognosticating dream. A potential prophetic dream narrative here would thus be shortened radically-condensed to a verse. ${ }^{21}$ Hamlet's first reaction to the appearance of the ghost is also noteworthy. Not Hamlet, but Horatio is the one who sees the spirit: "Look, my lord, it comes." (1.4.38) and interprets its gesture: "It beckons you to go away with it" (1.4.58); finally Hamlet: "It waves me forth again. I'll follow it. / [...] / Go on, I'll follow thee.” (1.4.68-79). Hamlet

19 See 1.2.226-242, e.g., “Arm'd, say you?” (1. 226), “From top to toe?” (1. 227), “What look'd he, frowningly?" (1. 230).

20 The uncertainty felt by the protagonist in face of the constellation of the early and unexpected death of his father and the rapid subsequent marriage of his mother to his uncle-now in possession of the crown-and the perceived unease about these events are articulated very clearly already at earlier stages; see Hamlet's first monologue, 1.2.129-158, esp. 132-134 and 150-158; his conversation with Horatio, esp. 1.2.174-183; his first scene with Gertrude and Claudius, 1.2.64129, esp. 68-75.

21 See Marjorie B. Garber, Dream in Shakespeare: From Metaphor to Metamorphosis (New Haven, CN/London: Yale University Press, 1974), p. 95. 
does not recognise the ghost as his father in the first place, he says that he rather exhibits a "questionable shape" (1.4.43), and, starting to talk to him, names him: “[...] I'll call thee Hamlet, / King, father, royal Dane. O answer me.” (1.4.44 f. $)^{22}$ When Hamlet finally follows the apparition, Horatio states with some concern: "He waxes desperate with imagination." (1.4.87).

Throughout the entire play, Hamlet is the only person who hears the ghost speak. That the ghost's words are attributable to Hamlet's imagination is thus a possible, plausible, if not obvious assumption. This may in particular be illustrated by considering the fourth scene of act three, where Old Hamlet's Ghost appears one last time. In the famous "closet scene," only the protagonist sees and hears him, in contrast to Gertrude. ${ }^{23}$ The queen can interpret the behaviour of her son only within the model of mental illness ("Alas, he's mad." 3.4.106; "This is the very coinage of your brain. / This bodiless creation ecstasy / is very cunning in.” 3.4.139-141). The aspect of madness or delusion represents a prominent and complex theme in Shakespeare's play, so that even the feigned madness must be considered a relevant variable in the plot-as Hamlet declares at the end of the first act: “[...] I perchance hereafter shall think meet / To put an antic disposition on" (1.5.179 f.). Claudius' ambition is to determine the reason for "Hamlet's transformation" (2.2.5; see 3.1.2-4). However, simulation, in the sense of deceiving the outside world and internal sensory deception are not always clearly separable in relation to Hamlet's remarks and behaviour. ${ }^{24}$

Although Hamlet accepts the charge of the ghost to avenge the murder of his father (see 1.5.29-31, 95-112), he does not take action. The doubts about the credibility of the ghost-and thus the foundation of the revenge entrusted to him, Claudius' actual guilt-remain $;{ }^{25}$ they culminate in the assumption that the

22 See also Küpper, “Hamlet and La vida es sueño,” p. 384, as well as pp. 380-384, regarding the role of the ghost in the scenes discussed above.

23 "HAM.: [...] What would your gracious figure? / [...] / GHOST: Speak to her, Hamlet. / HAM.: How is it with you, lady? / QueEn: Alas, how is't with you, / That you do bend your eye on vacancy, / And with th'incorporal air do hold discourse? / [...] / [...] Whereon do you look? / HAM.: On him, on him. [...] / [...] / [...] Do not look upon me, / Lest with this piteous action you convert / My stern effects. [...] / [...] / QUEEn: To whom do you speak this? / HAM.: Do you see nothing there? / QueEn: Nothing at all; [...] / HAM.: Nor did you nothing hear? / QuEEN: No, nothing but ourselves. / HAM.: Why, look you there, look how it steals away. / My father, in his habit as he liv'd! / Look where he goes even now out at the portal.” (3.4.105-138).

24 In this respect, Hamlet's encounter with Ophelia, immediately after the central monologue (3.1.89-163), and the scene of the funeral (5.1.210-294) should be mentioned.

25 On the one hand, to Horatio: "[...] Touching this vision here, / It is an honest ghost, that let me tell you." (1.5.143 f.), and on the other, when he "sees" the ghost for the first time: "Be thou a spirit of health or goblin damn'd, / Bring with thee airs from heaven or blasts from hell, / Be thy 
apparition of his dead father may have been a demon, a deception of the devil: "[...] The spirit that I have seen / May be a devil, and the devil hath power / T'assume a pleasing shape, yea, and perhaps, / Out of my weakness and my melancholy, / As he is very potent with such sprits, / Abuses me to damn me. [...]" (2.2.594-599). ${ }^{26}$

Hamlet's consciousness of the precarious reality-status of the ghost and thus his doubts about the reliability of his senses-Joachim Küpper calls him "the prototype of the contemporary sceptical intellectual"27-manifests itself in the plan to obtain certainty by other means concerning what has happened: “[...] I'll have grounds / More relative than this. The play's the thing / Wherein I'll catch the conscience of the King.” (2.2.599-601). As he states:

\section{[...] I have heard}

That guilty creatures sitting at a play

Have, by the very cunning of the scene,

Been struck so to the soul that presently

They have proclaim'd their malefactions.

For murder, though it have no tongue, will speak

With most miraculous organ. I'll have these players

Play something like the murder of my father

Before mine uncle. I'll observe his looks;

I tent him to the quick. If a do blench,

I know my course. [...]

(2.2.584-594)

This, however, contradicts Hamlet's previous observation:

Is it not monstrous that this player here,

But in a fiction, in a dream of passion,

Could force his soul so to his own conceit

That from her working all his visage wann'd,

Tears in his eyes, distraction in his aspect,

A broken voice, and his whole function suiting

With forms to his conceit? And all for nothing!

intents wicked or charitable, / Thou com'st in such a questionable shape / That I will speak to thee. [...]" (1.4.40-44), and, in a similar way, after its disappearance: "O all you host of heaven! 0 earth! What else? / And shall I couple hell? [...]" (1.5.92 f.).

26 First, the category of "demonic dream" should be mentioned here. The "power of the devil" resides in the manipulation of the inner perception, so that Hamlet may have been tricked by a supposedly "well-intentioned" form-the spirit of his dead father-but one that harbours deeply evil intentions in reality. Secondly, Hamlet's self-confessed melancholy is noteworthy in view of his disposition toward a highly active imagination.

27 Küpper, “Hamlet and La vida es sueño,” p. 389. 
For Hecuba!

What's Hecuba to him, or he to her, That he should weep for her? What would he do

Had he the motive and the cue for passion

That I have? [...]

(2.2.545-556)

Hamlet had previously instructed one of the arriving actors in the second act to recite a monologue from an Aeneid-play, ${ }^{28}$ where Aeneas tells Dido about Priam's slaughter (see 2.2.427-444). The clearly visible and convincing emotionality of the actor when he speaks of Pyrrhus' murder of Priam and especially the lamentation of Hecuba, refer not only to the "power" of the theatre and the craft of acting, but also to the ability of human beings to fake emotions ("What's Hecuba to him, or he to her[?]") and likewise to conceal them. The awareness of the possibility of simulation and dissimulation is in contrast to the notion of being able to obtain certainty about something based on the appearance of the gestures of a person ("I'll observe his looks; / I tent him to the quick. If a do blench, / I know my course."). ${ }^{29}$ In anticipation of what will be staged in the following, Hamlet thus articulates his doubts that the "test" of Claudius that is to be staged will provide certainty. The protagonist does not, however, content himself with this structure of isosthenia. He continues his search for certainty. "The Murder of Gonzago" (3.2.134-254), the play to be performed before the royal court, dramatises the core of what "motivates and plagues" the protagonist-the circumstances of his father's death; it is used in the form of an "experiment," Horatio being instructed as an observer of second order. ${ }^{30}$

28 The passage mirrors basic motifs of Shakespeare's play; the representation in Hamlet differs, however, from the version of Vergil, as well as from contemporary dramatic versions, for example, The Tragedy of Dido (1594) by Christopher Marlowe and Thomas Nashe (see Jenkins, "Longer Notes,” in: Shakespeare, Hamlet, pp. 421-571, pp. 477-481).

29 See Küpper, “Hamlet and La vida es sueño,” pp. 388 f.

30 "HAM.: There is a play tonight before the King: / One scene of it comes near the circumstance / Which I have told thee of my father's death. / I prethee, when thou seest that act afoot, / Even with the very comment of thy soul / Observe my uncle. If his occulted guilt / Do not itself unkennel in one speech, / It is a damned ghost that we have seen, / And my imaginations are as foul / As Vulcan's stithy. Give him heedful note; / For I mine eyes will rivet to his face, / And after we will both our judgements join / In censure of his seeming.” (3.2.75-87). Hamlet not only arranges the performance (HAM.: We'll hear a play tomorrow. / [To First Player] [...] Can you play The Murder of Gonzago? / FiRst Player: Ay, my lord. / HAM.: We'll ha't tomorrow night [...]” 2.2.530-534), but also supplements the script with a short speech he wrote himself (“[...] a speech of some dozen or sixteen lines, which I would set down and insert in’t [...].” 2.2.535 f.). What these "dozen or sixteen lines" may be, or if they are to be found in the "play within the play" at all, is debated (see the editor's notes as well as Jenkins, "Longer Notes,” pp. $481 \mathrm{f}$., 
When the murder finally takes place on stage, the performance is interrupted ("Ophelia: The King rises. / [...] Polonius: Give o'er the play. / KInG: Give me some light. Away.” 3.2.259-262). Although Hamlet feels at first entitled to derive the proof of guilt from the behaviour of the king ("HAM.: O good Horatio, I'll take the ghost's word for / a thousand pound. Didst perceive?” 3.2.280 f.), Horatio's neutral statements, which do not refer to any specific reaction of Claudius, show no certainty in this regard ("HoR.: Very well, my lord. / HAM.: Upon the talk of poisoning? / HoR.: I did very well note him.” 282-284). What is crucial, however, is that Hamlet introduces the "murderer" as "nephew to the King" (3.2.239). This puts the reason for Claudius' abrupt leaving of the performance up for discussion: he might not have seen the scene as an allusion to his own crimes, but rather to a potential assassination attempt by his nephew Hamlet. It is also noteworthy that during the "dumb-show" that precedes The Murder of Gonzago, whose plot it anticipates and which illustrates the poisoning in the garden, there is no reaction to be seen on the part of the royal couple. ${ }^{31}$ Claudius himself reveals that he is guilty of murdering his brother only in a soliloquy in the following scene ("O, my offence is rank, it smells to heaven; / It hath the primal eldest curse upon't- / A brother's murder. [...]" 3.3.36-38). ${ }^{32}$

In this way the true circumstances of his father's death remain hidden from Hamlet until the end of the play. Ultimately, he kills his uncle-just before his own violent death. But this is done only after the fatally wounded Laertes informs him of Claudius' intrigue concerning their duel and his plans concerning (Young) Hamlet's murder (see 5.2.316-333). Evidence about the reality status of the ghost and his words, about Claudius' guilt and thus the justification for revenge are not

p. 507). Ultimately, however, and in particular regarding the interpretative approach pursued here, this is not of high relevance.

31 Especially since the allusion to the murder of Hamlet's father appears quite explicit there. As the stage direction says: “The trumpet sounds. A dumb show follows. Enter a King and a Queen very lovingly, the Queen embracing him and he her. She kneels and makes show of protestation unto him. He takes her up and declines his head upon her neck. He lies him down upon a bank of flowers. She, seeing him asleep, leaves him. Anon comes in another Man, takes off his crown, kisses it, pours poison in the sleeper's ears, and leaves him. The Queen returns, finds the King dead, makes passionate action. The Poisoner with some Three or Four comes in again. They seem to condole with her. The dead body is carried away. The Poisoner woos the Queen with gifts. She seems harsh awhile, but in the end accepts his love." (3.2.133/134)

32 His pangs of conscience are already indicated at the beginning of this act: "PoL.: 'Tis too much prov'd, that with devotion's visage / And pious action we do sugar o'er / The devil himself. KING: [aside] O'tis too true. / How smart a lash that speech doth give my conscience. / The harlot's cheek, beautied with plast'ring art, / Is not more ugly to the thing that helps it / Than is my deed to my most painted word. / O heavy burden!” (3.1.49-54). 
obtainable by Hamlet until his own end-for the protagonist, there is no "solution" to this dilemma, it remains a constellation of skeptical isosthenia.

Hamlet's doubt is universal and radical. Later in Descartes the initially adopted possibility of a malicious deception caused by a "geniu[s] [...] malig$\mathrm{nu}[\mathrm{s}]^{\prime 33}$ is excluded by the axiomatic authority of a benevolent God; ${ }^{34}$ but for Hamlet the aspect of potential demonic deception remains virulent ("The spirit that I have seen / May be a devil"). ${ }^{35}$ While the radical skeptical doubt in the argument of the Meditationes will serve to overcome skepticism, ${ }^{36}$ the staging of the uncertainty in Hamlet does not lead to a proclamation of solid evidence, nor does it result in a propagation of Pyrrhonian serenity-quite the contrary. This manifests itself through the disastrous and gloomy end of the drama (Horatio is the only survivor; two families have been extinguished; Denmark will be captured by Norway under Fortinbras). And the protagonist's attitude of epoché leads to no ataraxia whatsoever. Hamlet himself qualifies his hesitation again and again as highly problematic ${ }^{37}$ and continues the search for certainty over large parts of the play. Completely in the spirit of Hamlet's remark at the end of the first act, "The time is out of joint. [...]" (1.5.196), uncertainty and ambiguity characterise Shakespeare's drama as a whole and are, so to speak, focused on the protagonist: “[...] Hamlet findet sich in einer Situation radikalen Ordnungsverlusts und des Zusammenbruchs aller bisherigen Gewißheiten." [Hamlet finds himself

33 "Supponam igitur non optimum Deum, fontem veritatis, sed genium aliquem malignum, eundemque summe potentem, \& callidum, omnem suam industriam in eo posuisse, ut me falleret: putabo coelum, aërem, terram, colores, figuras, sonos, cunctaque externa nihil aliud esse quam ludificationes somniorum, quibus insidias credulitati mea tetendit[.]" (Descartes, Meditationes, pp. $22 \mathrm{f}$.) ["I will suppose therefore that not God, who is supremely good and the source of truth, but rather some malicious demon of the utmost power and cunning has employed all his energies in order to deceive me. I shall think that the sky, the air, the earth, colours, shapes, sounds and all external things are merely the delusions of dreams which he has devised to ensnare my judgement.” (Descartes, Meditations, p. 15)]

34 See Descartes, Meditationes, pp. 34-52 (Meditatio 3), esp. pp. 41-52, pp. 53-62 (Meditatio 4), esp. p. 53, pp. 63-71 (Meditatio 5), esp. pp. 65-71, esp. p. 71, see also pp. 79 f. and p. 90; Descartes, Meditations, pp. 24-36 (Third Meditation), esp. pp. 28-36, pp. 37-43 (Fourth Meditation), esp. p. 37, pp. 44-49 (Fifth Meditation), esp. pp. 45-49, esp. p. 49, see also p. 55 and p. 62.

35 In his short comparison between Shakespeare and Descartes, John D. Cox sets Descartes' "demon hypothesis" in relation to Macbeth, however ("Shakespeare and the French Epistemologists," p. 32 f.).

36 See, e.g., Descartes, Meditationes, pp. 71-90 (Meditatio 6), esp. pp. 78-80, pp. 89 f.; see also p. 25, p. 27, pp. 28 f., pp. 34 f., pp. 37-40, pp. 68-71; Descartes, Meditations, pp. 50-62 (Sixth Meditation), esp. pp. 54-56, pp. 61 f.; see also pp. 16 f., p. 18, pp. 19 f., p. 24, pp. 25-28, pp. 47-49. 37 See, e.g., Hamlet’s soliloquy following the “player's scene,” 2.2.544-601, 544, 566-583; see also 4.4.32-66. 
in a situation radically deprived of order and all previous certainties], as Verena Lobsien puts it. ${ }^{38}$ This is also in close connection to the treatment of the dream in the play and in particular in its central monologue "To be or not to be" (3.1.5688). The contemplation of death and use of the metaphorical dream concept in this context expresses that there are only probabilities, no certainties for Hamlet. “[...] To die-to sleep, / No more; [...] / [...] / [...] 'tis a consummation / Devoutly to be wish'd. To die, to sleep; / To sleep, perchance to dream-ay, there's the rub: / For in that sleep of death what dreams may come" (3.1.60-66; my italics). At the end of life is sleep; but perhaps the life after death harbours comparable, if not immensely more difficult, hellish suffering than earthly life. ${ }^{39}$ That "the dread of something after death" not only ultimately outweighs the known evils to which man is exposed in this life, but also has an influence on his actions or non-action, is indicated in the last verses of the monologue. ${ }^{40}$ Confronted with the question of carrying out the revenge on Claudius or not, while being uncertain concerning his guilt, it is the fear of eternal damnation that makes the eponymous hero decide against taking action. Continuing this line of thought, to gain certainty becomes an enterprise of even vital dimensions.

La vida es sueño is supposed to have been written around thirty-five years after Shakespeare's play was composed and it is embedded in the cultural-historical context of Counter-Reformation Spain. The resulting "different treatment" of skepticism becomes all the clearer when reading it against the backdrop of Hamlet.

Although there is a traditional prophetic dream used in the beginning, or rather in the plot's prehistory, the focus of Calderón's drama is not on actual dreams. Clorilene, Segismundo's mother, while pregnant, had repeatedly dreamed of giving birth to a "monstrosity"- "un monstruo en forma de hombre" ["a bold / monster in human shape"], "[1] "[la] víbora humana del siglo" ["the

38 Olejniczak Lobsien, Skeptische Phantasie, p. 105.

39 "But that the dread of something after death [...] / [...] puzzles the will, / And makes us rather bear those ills we have / Than fly to others that we know not of?" (3.1. 78-82).

40 "Thus conscience does make cowards of us all, / And thus the native hue of resolution / Is sicklied o'er with the pale cast of thought, / And enterprises of great pitch and moment / With this regards their currents turn awry / And lose the name of action. [...]" (3.1. 83-88).

41 Pedro Calderón de la Barca, La vida es sueño [1636], ed. Ciriaco Morón, $31^{\text {st }}$ ed., Letras Hispánicas (Madrid: Cátedra, 2008), v. 672. All references to Calderón's play are to this edition and will be cited parenthetically by verse numbers in the text. The English translation is taken from Calderón, Life Is a Dream/La vida es sueño: A Dual-Language Book, ed. and trans. Stanley Appelbaum (Mineola, NY: Dover Publications, 2002). 
human viper of the age"] (v. 675) ${ }^{42}$-who would kill her, as we learn in the long speech given by the aging King Basilio (vv. 589-843, see vv. 660-675). We also learn that, indeed, Clorilene died in childbirth. His wife's dream and death form part of several dismal omens and observations related to Segismundo's birth,,$^{43}$ which lead Basilio to the prognostication that his only son and rightful heir to the throne would become an arrogant, cruel man and tyrannical ruler bringing disaster to the country and eventually overthrow and kill him. ${ }^{44}$ He spreads news in the kingdom that the newborn child had died and has his son secretly kept as a prisoner in a tower in the mountains. There he has him raised by Clotaldo, the king's confidant, without Segismundo knowing anything of his royal birth (vv. 738-759). When the son is an adult, Basilio decides to test him. The father wishes to find out whether or not the prophecy is true: "quiero examinar si el cielo / [...] / o se mitiga o se temple / por lo menos, y vencido / con valor y con prudencia / se desdice;" (vv. 1102-1110) ["I wish to determine whether heaven / [...] / can be assuaged, or at least / mollified, and whether, overcome / by merit and wisdom, / it can go back

42 Regarding the image of the "viper," see the interpretation in Frederick A. de Armas, "The Serpent Star: Dream and Horoscope in Calderón's La vida es sueño," Forum for Modern Language Studies 19 (1983), pp. 208-223, pp. 210-212.

43 "BASILIO: [...] [L]os cielos / se agotaron de prodigios. / [...] / [N]ació en horóscopo tal, / que el sol, en su sangre tinto, / entraba sañudamente / con la luna en desafío; / [...] / El mayor, el más horrendo / eclipse que ha padecido / el sol, después que con sangre / lloró la muerte de Cristo, / éste fue; [...] / [...] / Los cielos se escurecieron, / temblaron los edificios, / llovieron piedras las nubes, / corrieron sangre los ríos. / En este [...] / mortal planeta o signo / nació Segismundo dando / de su condición indicios, / pues dio la muerte a su madre [...]” (vv. 662-704) [“BAs.: (...) (T)he heavens / exhausted their miracles(.) / (...) / (H)e was born at such an astrological conjunction / that the sun, tinged with its blood, / was fiercely entering / into a joust with the moon(;) / (...) / The greatest, most terrifying / eclipse ever suffered by / the sun from the time when it bloodily / bewailed the death of Christ / was this one(;) (...) / (...) / The sky was darkened, / buildings shook, / the clouds rained stones, / the rivers ran blood. / Under this (...) / fatal planet or sign / Segismundo was born, giving / an indication of his nature, / because he killed his mother."]

44 "BAS.: Yo, acudiendo a mis estudios, / en ellos y en todo miro / que Segismundo sería / el hombre más atrevido, / el príncipe más cruel / y el monarca más impío, / por quien su reino vendría / a ser parcial y diviso, / escuela de las traiciones / y academia de los vicios; / y él, de su furor llevado, / [...] / había de poner en mí / las plantas, y yo rendido / a sus pies me había de ver: / [...] / siendo alfombra de sus plantas / las canas del rostro mío.” (vv. 708-725) [“BAS.: I, referring to my books, / found in them, and in all things, / that Segismundo would be / the most insolent man, / the most cruel prince, / and the most impious monarch, / through whom his kingdom would come / to be fragmented and divided, / a school for treason / and an academy of vice; / and that he, carried away by his fury, / (...) / would one day set his foot / on me, and that I, surrendering / would find myself groveling before him / (...) / the gray hairs of my beard / serving as a carpet to his feet."] See also vv. 604-606, vv. 612-643, for Basilio as a scientist and the basis for his prognosis, the science of astrology. 
on its word;"]..$^{45}$ If the prince proves to be a good ruler contrary to the prediction, he will ascend the throne. ${ }^{46}$ Should he, however, "haughtily, boldly, insolently, / and cruelly give[s] free rein / to his vices" ("soberbio, osado, atrevido / y cruel con rienda suelta / corre el campo de sus vicios” vv. 817-819), he will be imprisoned forever (vv. 824 f.). ${ }^{47}$ For the purpose of this test, Segismundo is drugged with a narcotic and brought to the palace in order to rule. ${ }^{48}$

The discussion of the play's central theme already stated in its title starts at this point and is intimately connected to the drama's concern with the contemporary debate about skepticism. ${ }^{49}$ Calderón's comedia advances the core skeptical thesis of the unreliability of the senses with a firmly established element in the skeptics' repertoire, namely the problem of being able to distinguish between the state of dreaming and of wakefulness, which refers verbatim to the fourth trope of Sextus Empiricus mentioned above. The mode of representation used to put skepticism on stage is, structurally speaking, a sort of play-within-a-play, a play whose protagonist is not aware of his role. Segismundo's skepticism and the related questions concerning the ethical-practical realm are generated only

$45 \mathrm{~J}$. Küpper interprets "[...] Basilio as a literary model of emerging Empiricism [...]." ("Hamlet and La vida es sueño," p. 398): "Basilio’s procedural mode can be summarized as follows: first observing nature, then trying to systematize the data and organize them according to the principle of causality [...], and finally, based on this analysis, venturing a prognostication in order to control future contingency. [...] [T] he aim pursued by Basilio [...] [is] to reduce possible misfortune [...]." (ibid.). In view of the "message" of the play-this should be mentioned alreadyBasilio represents one of those figures who "fail." In this way, the concept of "modernity" (for which he stands) is also "rejected" through the plot development of the play (see on this aspect pp. 396-399 and esp. Küpper, “La vida es sueño,” pp. 392-399). The philosophical basis of this strain of modern epistemology emerging in the seventeenth century is skepticism (the reference point being primarily the second tradition of ancient skepticism, Academic skepticism): sensory perception can deceive; hence, the results are always subject to potential revision. If Calderón's play formulates a critique of the emerging, modern paradigm of empiricism, it is also an implicit criticism of (here: Academic) skepticism.

46 "BAs.: [...] siendo / prudente, cuerdo y benigno, / desmintiendo en todo al hado / que dél tantas cosas dijo, / gozaréis el natural / príncipe vuestro [...]” (vv. 808-813) [“(...) if he is / prudent, sane, and beneficent, / and completely gives the lie to the prophecy / that said all those things about him, / you will enjoy the presence of your / natural prince (...)"].

47 In the latter case, Astolfo and Estrella, the king's nephew and niece, will ascend the Polish throne as a royal couple (vv. 831-835).

48 See Clotaldo's account, vv. 989-1087.

49 This concerns the play's main plot with its protagonist Segismundo. However, see also how already Clotaldo, after his first conversation with Rosaura (dressed as a man and carrying his sword), is faced with doubts about the reliability of his sensory perception linked to the question of the (morally) right action, ultimately taking a classic skeptical position, i.e. abstaining from taking a decision and from taking action, vv. 395-468. 
by the orchestration of his father, who undertakes this approach so he can tell his son (in the event that he fails the test) that his experience as a ruler had only been a dream. ${ }^{50}$

When Segismundo, disoriented and confused, awakens in the royal palace, he says the following:

\author{
SEgismundo: \\ ¡Válgame el cielo! ¿Qué veo? \\ ¡Válgame el cielo! ¿Qué miro? \\ Con poco espanto lo admiro, \\ con mucha duda lo creo. \\ ¿Yo en palacios suntuosos? \\ ¿Yo entre telas y brocados? \\ ¿Yo cercado de criados \\ tan lucidos y briosos? \\ ¿Yo despertar de dormir \\ en lecho tan excelente? \\ ¿Yo en medio de tanta gente \\ que me sirva de vestir? \\ Decir que sueño es engaño, \\ bien sé que despierto estoy. \\ ¿Yo Segismundo no soy? \\ Dadme, cielos, desengaño. \\ [...] \\ Pero sea lo que fuere, \\ ¿quién me mete en discurrir? \\ Dejarme quiero servir, \\ $\mathrm{y}$ venga lo que viniere. \\ (vv. 1224-1247)
}

50 See the whole passage, vv. 1120-1149, in whose last verses Basilio supplements the measure using the play's title metaphor, formulated here for the first time, which will in the course of the play, and in view of the "transformation" of the protagonist, become increasingly relevant, being itself subject to a change in meaning ("podrá entender que soñó / y hará bien cuando lo entienda, / porque en el mundo, Clotaldo, / todos los que viven sueñan.” [vv. 1146-1149; my italics] ["he will be able to surmise that it was a dream; / and it will be a good thing for him to realize, / because in this world, Clotaldo, / everyone who lives is a dreamer"]). Even if the corresponding meaning within the context of the Segismundo plot still remains to be discussed, it may be noted that, according to the reading supported here, this reference to "life is a dream" stands in connection to the skeptical notion of the indistinguishability of waking and sleeping. If Basilio implies that because of this it would be irrelevant whether Segismundo lives in a palace or in a prison, this can be seen as a reference to the skeptics' moral indifferentism. The problem here is in particular-and this represents from the play's point of view a configuration directed against skepticism -that Basilio applies this indifference only to the life of his son but not to himself, since the aim of his own actions is to prevent being deprived of his status. 
[SEG.: Heaven help me! What's this I see? / Heaven help me! What do I behold? / I marvel at it with little fear, / but I believe it only with great doubt. / I in a luxurious palace? / I amid fabrics and brocade? / I surrounded by such well-dressed, / energetic servants? / I awakening from sleep / in such an excellent bed? / In the midst of so many people / helping me to dress? / To say I'm dreaming is mistaken, / I know very well I'm awake. / Am I not Segismundo? / Heavens, clarify my confusion! / (...) / But, whatever it may be, / who's forcing me to ponder it? / I want to let myself be served, / come what may.]

On account of the entirely new situation in which he finds himself, Segismundo doubts the reality of his sensory impressions. In a classic skeptical manner, he wonders if he is awake or dreaming. Then he interjects that the perceptions that appear so doubtful to him could not be a dream, since he knows with certainty that he is awake. Attempting to reassure himself, he asks whether he might not be himself, not Segismundo. His current perceptions cannot be reconciled with his life until that point, with his existence as a prisoner in the tower, because after all Segismundo does not know at this time that he is a prince. ${ }^{51}$ In order to gain certainty, the protagonist attempts, somewhat unsuccessfully, to construct the argument that Descartes would later advance to refute the skeptical dream trope. Based on the examination of whether continuity can be established between perceptions appearing doubtful at the moment and the life led up to that point, the dreaming and the waking state can be held distinct from each other according to Descartes' argumentation. ${ }^{52}$ Gripped by uncertainty, Segismundo pleads to heaven in a ritual and formulaic way for desengaño, that is, to be freed of his possible delusion. However, the "right way" implicitly suggested from the perspective of the play is first abandoned by Segismundo. Pondering further about whether he is dreaming or awake appears to him to be irrelevant, but regarding his actions the conclusion he draws is to enjoy to the fullest the amenities and comforts that he subjectively perceives as real ("Pero sea lo que fuere, / ¿quién me mete en discurrir? / Dejarme quiero servir, / y venga lo que viniere." vv. 1244-1247). The following scene in the palace is characterised by Segismundo's violent actions

51 As the "director" Basilio says, later he will be informed by Clotaldo of his royal descent and the circumstances that led to his life in isolation (vv. 1268-1294).

52 See Descartes, Meditationes, pp. 89 f. ("Cum vero eae res occurrunt, quas distincte, unde, ubi, \& quando mihi adveniant, adverto, earumque perceptionem absque ulla interruptione cum tota reliqua vita connecto, plane certus sum, non in somnis, sed vigilanti occurrere.” p. 90); Descartes, Meditations, pp. 61 f. ("But when I distinctly see where things come from and where and when they come to me, and when I can connect my perceptions of them with the whole of the rest of my life without a break, then I am quite certain that when I encounter these things I am not asleep but awake." p. 62). The references to the skeptical "dream trope," and the connection to Descartes' argumentation, are already to be found in Küpper, “La vida es sueño," esp. pp. 399 f., p. 400, n. 46, p. 401, n. 50. 
aimed at fulfilling his desires. ${ }^{53}$ In short, he does not pass the test arranged by his father. Consequently, Basilio has him transported back to his prison while putting him to sleep once again. When he awakens in this familiar environment and is convinced by Clotaldo that what he experienced in the palace was just a dream (vv. 2092-2108), the doubts about the reliability of his sensory perception increase compared to the selective uncertainty experienced the first time he awoke. In terms of perception, he cannot distinguish between his current experience and the experience in the palace that has been explained to him by Clotaldo as a dream, so he ponders the possibility that he is dreaming even now: "SEG.: [...] si ha sido soñado, / lo que vi palpable y cierto, / lo que veo será incierto; / y no es mucho que rendido, / pues veo estando dormido, / que sueñe estando despierto." (vv. 2102-2107) [“(...) if what I saw palpably and surely / was just a dream, / what I see now is probably doubtful; / and it wouldn't be a surprise that, / if I see clearly while asleep, / I should dream while awake." ${ }^{54}$

The conclusion drawn by him consists in the skeptical thesis of fundamental doubt concerning the reliability of sensory perception. This is expressed metaphorically in Segismundo's famous monologue at the end of the second jormada. All of life is a dream, concludes the protagonist: “QQué es la vida? Un frenesí. / ¿Qué es la vida? Una ilusión, / una sombra, una ficción, / y el mayor bien es pequeño, / que toda la vida es sueño, / y los sueños, sueños son.” (vv. 2182-2187) [“What is life? / A frenzy. / What is life? An illusion, / a shadow, a fiction, / and our greatest good is but small; / for, all of life is a dream, / and even dreams are dreams."].55

53 These radically self-centred actions (following the passage quoted above and the "maxim" uttered later, "Nada me parece justo / en siendo contra mi gusto." [vv. 1417 f.] ["Nothing seems right to me / if it goes against my grain."]), initially staged as a consequence of Segismundo's indissoluble doubt about the reality status of his perceptions and conveying to that extent a critique of skepticism, include one murder (vv. 1422-1431), three attempted killings (e.g., vv. 16801693) and one attempted rape (vv. 1624-1667). Regarding the implication of hedonism, see Küpper, “La vida es sueño,” pp. 406 f. See also Everett W. Hesse’s description: “Since no 'desengaño' is forthcoming to relieve the anxiety arising from his inability to explain his predicament, he [Segismundo] finds it easier to allow his behavior to follow the pleasure principle [...]." ("The Role of Deception,” pp. $121 \mathrm{f}$.; my italics).

54 See the similar line of argument in Descartes' first Meditatio (Descartes, Meditationes, p. 19; Descartes, Meditations, p. 13), and more explicit in the sixth Meditatio (Descartes, Meditationes, p. 77; Descartes, Meditations, p. 53). See also the reference in Küpper, “La vida es sueño,” p. 401, n. 47. Furthermore, see the respective passage in Montaigne's Apologie (Michel de Montaigne, Apologie de Raimond de Sebonde, Essais 2:12 [1580-1588], in: Les Essais, edd. Jean Balsamo, Michel Magnien, Catherine Magnien-Simonin, and Alain Legros, Bibliothèque de la Pléiade [Paris: Gallimard, 2007], pp. 458-642, pp. 633 f.).

55 According to J. Küpper's apt interpretation: “[...] [Segismundo] draws a conclusion that we could understand as the transition from the literal meaning of the concept of 'dream' to a 
But the play does not stop at this reference to the basic tenet of skepticism. It is Clotaldo who reminds Segismundo that epistemological uncertainty does not suspend the validity of basic ethical norms: "Segismundo, que aún en sueños / no se pierde el hacer bien.” (vv. 2146 f.) [“CLotaldo: Segismundo, because even in dreams / good deeds are never wasted.”] ${ }^{56}$

When Segismundo is freed from the tower at the beginning of the third jornada by rebels who seek to prevent foreign rule and install the legitimate successor on the throne, he is once again faced with the problem of adequately classifying his perception. And due to his previous experience, he also considers to be an illusion what he is experiencing now: "SEG.: [...] Ya / otra vez vi aquesto mesmo / tan clara y distintamente / como agora lo estoy viendo, / y fue sueño. [...]” (vv. 2348-2352) [“(...) Once before / in the past I saw the very same thing / just as clearly and distinctly / as I see it now, / and it was a dream.”].57

metaphorical one. If, indeed, we cannot trust our sensory perceptions to distinguish the real from the unreal (or fictitious), if 'life' ('la vida') is 'una ilusión, una sombra, una ficción,' then the proposition 'toda la vida es sueño' [...] is true, not in the sense that one would always be dreaming, but in the sense that everything we experience is unreliable. One could call this step in Segismundo's intellectual development the stage of classical Pyrrhonian Scepticism, that is, of radical doubt." (“Hamlet and La vida es sueño," p. 372; see also Küpper, "La vida es sueño," pp. $401 \mathrm{f}$.$) .$

56 In anticipation of the discussion below of the third jornada, the play's Christian-Catholic frame should be pointed out. In Bárbara Mujicas words: "The truth comes to Segismundo not through reflexion or observation but through revelation. Clotaldo, the teacher, articulates God's message, even though he does not identify it as such: 'aún en sueños / no se pierde el hacer bien' [...]. Man must act, for it is through his actions that he will be judged after death." ("Calderón's La vida es sueño and the Skeptical Revival,” p. 29). See also Segismundo's first verses ("Es verdad; pues reprimamos / esta fiera condición, / esta furia, esta ambición, / por si alguna vez soñamos.” vv. 2148-2151 [“It's true, then: let me restrain / my fierce nature, / my fury, my ambition, / in case I ever dream again.”]), which show his readiness now to suppress those impulses to which he gave way uncontrollably during the palace episode. See, moreover, vv. 2158-2164, vv. 2168-2177, for the evocation of images of the transience of earthly goods and all worldly existence, and vv. $2156 \mathrm{f}$., for an allusion to the horizon of the Christian afterlife.

57 "SEg.: [...] [S]é / que toda esta vida es sueño, / idos, sombras, que fingís / hoy a mis sentidos muertos / cuerpo y voz, siendo verdad / que ni tenéis voz ni cuerpo; / que no quiero majestades / fingidas, pompas no quiero, / fantásticas ilusiones / [...] / Para mí no hay fingimientos; / que, desengañado ya, / sé bien que la vida es sueño.” (vv. 2320-2343; italics in the original) [“(S)ince I know / that all of this life is a dream, / away with you, you shadows that today / pretend to my numbed senses / that you have a body and a voice, / though the truth is you have neither voice nor body; / for I don't want majesty / that is feigned, I don't want pomp / that is imagery, illusions / (...) / For me there is no more pretense, / because now, undeceived, / I know perfectly well that life is a / dream."]. When one of the soldiers attempts to dispel Segismundo's suspicion of deception by referring, as an indication of the reality of their undertaking, to the large number of his subordinates whom he can see by looking out in the mountains (vv. 2344-2348), Segismundo 
Nevertheless, after initial hesitation (see vv. 2307-2352), the Polish prince decides to comply with the request of the soldiers and to march against the army of his father in the struggle to establish his legitimate rule. He decides to act. This action, however, is no longer subordinate to satisfying his own desires, but is undertaken in the general public interest: ${ }^{58}$ Segismundo thus reconfirms the lesson taught by Clotaldo: "SEg.: [...] sea verdad o sueño, / obrar bien es lo que importa; / si fuere verdad, por serlo; / si no, por ganar amigos / para cuando despertemos.” (vv. 2423-2427) [“(...) whether it's reality or a dream, / to do good is what matters; / if it should be reality, just because it is good; / if not, for the sake of winning friends / for the time when we awaken." $]^{59}$ It is the "obrar bien," "to do good; to do right," which the protagonist elevates to a maxim of his actions. And this imperative applies in waking as well as in dream states. The dream-life metaphor now refers to the Christian metaphysical framework of this world and the hereafter. And the implication of the Counter-Reformation dogma is that one's actions on earth (in the state of dream) are decisive for the afterlife which is the "real" waking state.

The liberation by the soldiers, as well as the subsequent encounters and events, ${ }^{60}$ are ultimately able to substantiate for Segismundo that what had happened in the palace was reality and not just a dream. But he does not interpret this evidence as a guarantee of certainty, in the sense of the continuity argument later developed by Descartes. From Segismundo's perspective, there is no reliable distinction between reality and dream, reality and illusion, truth and deception,

replies with the lines quoted above-using a formulation that also features prominently in the context of Cartesian philosophy. Segismundo's expression of doubt refers to the unreliability of perception: even if this is "clear and distinct," it does not convey any certainty concerning the ontological status of what is perceived and may just as well turn out to be a deception. For Descartes, however-and this difference is crucial-, the formulation "clear and distinct" (clare et distincte) occurs in the context of the requirements for the concepts linked to the guarantors of certainty, the innate ideas. See, e.g., Descartes, Discours de la méthode [1637], in: Euvres de Descartes, vol. 6, pp. 1-78, pp. 11-22, esp. p. 18 (Descartes, Discourse on the Method, in: The Philosophical Writings of Descartes, vol. 1, pp. 111-151, pp. 116-122, esp. p. 120); Descartes, Principia philosophiae [1644], in: Euvres de Descartes, vol. 8:1, p. 21 f. (Descartes, Principles of Philosophy, in: The Philosophical Writings of Descartes, vol. 1, pp. 193-291, p. 207 f.); Descartes, Meditationes, pp. 35-40 (Descartes, Meditations, pp. 24-28). See in this respect Henry W. Sullivan's analysis (“Tam clara et evidens") and also Küpper, “La vida es sueño,” p. 408, n. 71.

58 "Seg.: Vasallos, [...] / [...] en mí lleváis / quien os libre, osado y diestro, / de extranjera esclavitud. / Tocad al arma [...] / [...] / Contra mi padre pretendo / tomar armas [...]” (vv. 2373-2380) ["Vassals, (...) / (...) in me you have / a man who will boldly and skillfully free you / from foreign servitude. / Sound the alarm (...) / (...) / I intend to take arms / against my father (...)”].

59 See also vv. 2359-2372, vv. 2399-2401.

60 See the encounters with Clotaldo (vv. 2387-2427) and esp. with Rosaura (vv. 2690-3015). 
original and copy. ${ }^{61}$ Even the momentary realisation that the experience in the palace was not a dream but reality could be the result of a universal deceit (in the sense of the genius malignus hypothesis later proposed by Descartes). ${ }^{62}$

One can understand the doubt as it is presented in La vida es sueño using Descartes' term "hyperbolic doubt."63 The result of overcoming skepticism by means of rhetoric, undertaken in Descartes, leads to rationalism, which lays the ground for modernity. ${ }^{64}$ In Calderón, skepticism is not overcome epistemologically (epistemologically, the comedia ultimately stands in continuity with Pyrrhonism), but in terms of moral philosophy in line with Catholic dogmatics. The certainty question is repositioned: the question of whether sensory perception is reliable or not is irrelevant to earthly life. Of relevance is the dimension of the beyond, which is the place of true life, of certainty, of the waking state (a category that does not exist from a skeptical perspective). Orientation for the disoriented is provided by Christian faith and the moral-theological principles for practical action as taught by the Church: it is the "obrar bien," the right course of action, through which man can "earn" the "true life" after death. Segismundo formulates this lesson as follows:
[...] ¡con mis razones propias vuelvo a convencerme a mí!
Si es sueño, si es vanagloria, ¿quién, por vanagloria humana, pierde una divina gloria?
[...]
[...] si sé

61 See vv. 2938-2949: “¿[...] [T]an parecidas / a los sueños son las glorias, / que las verdaderas son / tenidas por mentirosas, / y las fingidas por ciertas? / ¿Tan poco hay de unas a otras / que hay cuestión sobre saber / si lo que se ve y se goza, / es mentira o es verdad? / ¿Tan semejante es la copia / al original, que hay duda / en saber si es ella propia?” [“Are glories (...) / so similar to dreams / that real ones / are considered fictitious / and feigned ones true? / Is there so little difference between them / that it's questionable knowledge / whether what one sees and enjoys / is a lie or the truth? / Is the copy so similar / to the original that doubt arises / as to which is which?”]

62 See Küpper, “La vida es sueño,” p. 404, n. 57; Lema-Hincapié, “¿Existir en sueño o en vigilia?," p. 59, who both compare the Basilio of the first and second acts with Descartes' "demonic deceiver."

63 Descartes, Meditationes, p 89 (“hyperbolicae [...] dubitationes”); Descartes, Meditations, p. 61 ("exaggerated doubts"). With regard to Calderón's representation in dramatic form, the "play-within-the-play"-like structure is a crucial element: Segismundo's skeptical doubts about the reliability of his senses are triggered by means of Basilio's staged artificial dream.

64 It should be recalled that Cartesian autonomous realism ultimately also only works if one excludes the thesis of a "malicious demon" as ruler of the world. 


\begin{abstract}
que es el gusto llama hermosa
que la convierte en cenizas

cualquiera viento que sopla, acudamos a lo eterno,

que es la fama vividora,

donde ni duermen las dichas,

ni las grandezas reposan.
\end{abstract}

(vv. 2967-2985)

[I convince myself (...) / with my own reasoning! / If it's a dream, if it's vainglory, / who, in exchange for human vainglory, / would lose a divine glory? / (...) / (...) if I know / that pleasure is a lovely flame / that is turned to ashes / by any wind that blows, / let us look to eternity, / which is everlasting fame / where good fortune does not sleep / and grandeur does not take repose!]

In relation to the position toward skepticism taken in the comedia, I would like to mention two further aspects. It is the insight granted to Segismundo that makes him become a good Catholic Christian and Christian ruler, rather than a skeptical adherence to the "traditions of the ancestors" (in this case: Catholicism). In accordance with the Christian concept, Segismundo's attitude is an activist one, which stands in marked contrast to the skeptical course of non-action. In keeping with the genre, the ending of the comedia is harmonious, with the new ruler Segismundo subordinating his own wishes to the "general good" and the restoration of order. ${ }^{65}$

65 The "reformed" Segismundo not only curbs his anger against his father (after having defeated the king's army, he submits to Basilio, who in turn transfers the crown to his son [vv. 3146-3253]), he also renounces his own desire for Rosaura and finally orders Astolfo to marry her (vv. 29582992, vv. 3005-3015, vv. 3255-3261); he himself will take Estrella as bride (vv. 3278-3287). At the end of the play, the kingdom is pacified, rule is stable, lost honour is restored through marriage, the dynastic problem is resolved by another marriage of convenience. With regard to the aspect of prudentia (the virtue that in traditional Christian moral theology primarily determines the hacer bien, the good action on earth), see, e.g., in more detail the already mentioned third encounter between Segismundo and Rosaura, here vv. 2950-2993. What is presented there is once again the temptation to allow moral indifference to prevail and to give in to passio, sensual desire; to put it plainly, Segismundo, as in the palace scene, again thinks of raping Rosaura (vv. 2954-2962). With the transformed Segismundo, however, ratio gains the upper hand ("Mas ¡con mis razones propias / vuelvo a convencerme a mí!" [vv. 2967 f.]) on the basis of the insight: “¿quién, por vanagloria humana, / pierde una divina gloria?” (vv. 2970 f.); “acudamos a lo eterno” (v. 2983). According to Tridentine dogma, for the baptised, it is possible to resist sinful temptation by using God-given reason. One could also say that reason (of the baptised) is able to control the will successfully. Suppressing his own desire, Segismundo now wants to restore Rosaura's honour and to pursue his intention to regain the crown (vv. 2986-2993); as royal ruler he will marry her off to the person with whom she has had a (secret) affair in the past. 
Calderón composed two other plays with the same title as his famous comedia discussed here. A first version of the auto sacramental called La vida es sueño originated around the same time as the comedia, and a second version, provided with a loa, was written by Calderón in his later period, on the occasion of the Corpus Christi celebration in Madrid in 1673. This latter was first printed in 1677 in the Primera parte de autos sacramentales. ${ }^{66}$ The dream-auto cannot be discussed in detail here and it is not intended to interpret it as an allegorical explanation for the comedia. In order to contextualise (and substantiate) what has been argued above, some remarks concerning the auto may be made. The auto sacramental is especially suited to shed light on the reasons why Calderón addresses skepticism in his best-known work and why he gave this treatment precisely the direction found in the comedia.

The auto renders immediately evident that an author of the Counter-Reformation ultimately cannot help but take a skeptical position as far as epistemology is concerned: with regard to the most sublime of the truths of faith, the real presence of Christ in the consecrated bread and wine, the senses do not lead the way to truth, they deceive and not only occasionally, but systematically. What the believer sees and tastes is bread (and wine). ${ }^{67}$

66 See Fernando Plata Parga, "Introducción," in: Calderón, La vida es sueño: Edición crítica de las dos versiones del auto y de la loa, ed. Plata Parga, Teatro del Siglo de Oro: Ediciones críticas (Kassel: Reichenberger; Pamplona: Universidad de Navarra, 2012), pp. 11-64, pp. 25-27, pp. 35-38 and pp. 45-47. The performance of the autos sacramentales formed part of the celebrations in worship of the Eucharist and the mystery of transubstantiation. The doctrine of transubstantiation, reaffirmed in the resolutions of the Council of Trent-the (permanent) real presence of Jesus Christ's body and blood in the consecrated substances of bread and wine-is one of the Catholic Church's dogmas most disputed by Protestantism. See Canones, et decreta sacrosancti oecvmenici, et generalis Concilii Tridentini svb Pavlo III, Ivlio III, Pio IIII, Pontificibvs max[imis] (Mediolanum: Antonius Antonianus, 1564), Sessio 13, 11 October 1551: "Decretum de sanctisimo Eucharistiæ Sacramento," fols. 29v-32r, esp. Caput 1 "De reali præsentia Domini nostri Iesu Christi, in sanctisimo Eucharistiæ Sacramento," fols. 29v-30r, Caput 4 "De transubstantatione," fol. 30v, Canones 1, 2, 4 and 8, fols. 31v-32r; The Canons and Decrees of the Sacred and Ecumenical Council of Trent: Celebrated under the Sovereign Pontiffs Paul III, Julius III, and Pius IV, trans. James Waterforth (London: Dolman, 1848), Session the Thirteenth, 11 October 1551: "Decree concerning the most holy sacrament of the Eucharist," pp. 75-84, esp. chap. 1 "On the real presence of our Lord Jesus Christ in the most holy sacrament of the Eucharist," p. 76, chap. 4 "On Transubstantiation,” p. 78, Canons 1, 2, 4 and 8, pp. 82 f. This doctrine stipulates that sensory perception is unable to distinguish between a consecrated host and non-consecrated bread and wine, but that the former is different from the latter in "essence" or "substance," and therefore also in their effective power; according to Catholic dogma, the reception of the Eucharist is of fundamental importance for the salvation of the soul.

67 With regard to this auto sacramental it is in particular the loa that has to be mentioned. Set in the context of the dogma of Eucharistic transubstantiation, it represents an allegorically drama- 
In terms of praxis, however, to adopt the ancient skeptics' indifference and "acquiescence in that which is" as a guideline for action would be unacceptable from a Christian point of view, as is evidenced not least by the auto La vida es sueño, whose action follows the genre's typical basic structure of Creation, Fall and Redemption. ${ }^{68}$ For that "which is," is a fallen world; and adhering to it would

tised critique of the reliability of sensory perception and, related to this, the accentuation of the relevance of faith (and tradition). The allegorical figures of the five senses (Vista, Oído, Olfato, Gusto and Tacto) enter into an archery competition, their target being the Host and Chalice hanging at the top of a Cross. Vision, Smell, Touch and Taste fail, only Hearing succeeds and hits the target, because: “OíDo: La Fe que allí hay cuerpo y alma / y carne y sangre me ha dicho; / y pues sentido de Fe / es solamente el Oído, / crea el Oído a la Fe / y no a los demás sentidos. / Que si la Vista, el Olfato, / el Tacto y el Gusto han visto, / tocado, olido y gustado / pan, es porque no han creído / que solos los accidentes / duran en aquel divino / milagro de los milagros, / [...] / no la substancia de pan, / pues con poder infinito / transubstanció la substancia / del pan en carne y del vino / en sangre[.] [¿][q]ui[e]n es la misma / verdad que imperiosa dijo: / 'Este es mi cuerpo y mi sangre' / con alma y vida[?] [...]” [HEARING: Faith has told me that there are body and soul / and flesh and blood; / and since the sense perception that belongs to Faith / is Hearing alone, / will the sense of Hearing believe Faith / and not what the other senses tell. / If the senses of Vision, Smell, / Touch and Taste have seen, / touched, smelled and tasted / bread, it is because they did not believe / that only the accidents / remain in this divine / miracle of miracles, / (...) / but not the substance of bread, / since by means of infinite power / transubstantiated the substance / of the bread into flesh and that of the wine / into blood he who is the same / truth as the one that (with soul and life) imperiously said: / 'This is my body and my blood' / (...).] (Calderón, Loa para el auto intitulado La vida es sueño, in: Calderón, La vida es sueño: Las dos versiones del auto y de la loa, pp. 83-101, vv. 223-244; my translation). On the unreliability of sensory perception in the context of the sacrament of the Eucharist, see Thomas Aquinas, Summa theologiæ $3^{\text {a }}$ q. 75 a. 5, esp. co., ad. 2 and ad. 3 (Thomas Aquinas, Summa Theologiæ: Latin Text and English Translation, Introductions, Notes, Appendices and Glossaries, ed. Thomas Gilby, 61 vols. [London: Blackfriars/Eyre \& Spottiswood; New York, NY: McGraw-Hill, 1964-1973; repr. Cambridge/New York, NY: Cambridge University Press, 2006], vol. 58: The Eucharistic Presence ( $3^{\mathrm{a}}$ 73-78), ed. and trans. William Barden, pp. 72-77, esp. pp. 74 f., pp. 76 f.).

68 See Calderón, Auto sacramental intitulado La vida es sueño [segunda versión; 1673], in: Calderón, La vida es sueño: Las dos versiones del auto y de la loa, pp. 105-199. For a small insight and contextualisation of what follows, I give a brief summary of the auto: The Four Elements (Agua, Aire, Tierra, Fuego) fight against each other, until Poder [Power], Sabiduría [Wisdom] and Amor [Love] (the Three Persons of the Holy Trinity) appear. These announce the creation of El Hombre [Man]. He will be endowed with Entendimiento [Understanding], by means of which he is capable of distinguishing between good and evil, and with Albedrío [free Will], which makes him able to act according to the bad as well as to the good. He will be able to rule and control the Elements and, furthermore, to gain Gracia [divine Grace] as a wife, if he passes the test: El Hombre will be brought to a splendid palace without him knowing of his role as God's crown prince; if he does not behave well, but in an arrogant and disobedient way, he will be expelled. La Sombra [Shadow/Darkness] and El Príncipe de las Tinieblas [The Prince of Darkness; Lucifer] lament on the occasion of the creation of Man. El Hombre is released from the prison of Non- 
mean to fall prey to sin. Christian ethics is decidedly activist; according to the Catholic view, seizing the possibility to oppose sin and to accept God's grace is placed in the (free) will of the (baptised) individual. But this "will to do the good" ultimately eludes all knowing. The right and good action is not based on knowledge; it is based on a higher, non-rational insight, the truth of which remains epistemologically unconfirmed and can attain persuasive power only rhetorically. Considering that Segismundo at the end of La vida es sueño is, within the limits of earthly possibility, a happy man, there is an implicit promise that the obrar bien not only guarantees otherworldly happiness, but also allows for a certain contentment already in one's earthly existence.

Drawing on DramaNet's theoretical conceptualisation of culture as a network, the revival of ancient skepticism in early modern Europe is an example of the extraction of floating material available in the cultural net. As this essay illustrates, the usage of this material pertained also to the two great theatre cultures of the time. ${ }^{69}$

Despite all their significant differences-in terms of genre, date of origin, linguistic and cultural context, or ideological agenda-both plays stage Pyrrhonian skepticism's basic assumption of the unreliability of sensory perception,

being, accompanied by Gracia who carries a torch. In the palace, El Hombre is amazed to find himself acclaimed, but soon full of pride he insists on his own free will and freedom of action. The advice and warnings given by Entendimiento seem a nuisance to him, and he prefers to turn to pleasure and Albedrío's flattery. Sombra and El Prínicpe de las Tinieblas (now Pecado [Sin]), in disguise, offer him a poisoned apple. Entendimiento warns him of the disastrous deceptiveness of his senses and wants him to use reason, while Albedrío encourages him to pursue sensory delights. El Hombre hurls Entendimiento down a rock (with the help of Albedrío) and eats the apple, then he falls into a deathlike sleep. When El Hombre awakes in his dark prison, he wonders whether all this has been a dream. But he is now put in chains and when he calls Luz/Gracia [Light/Grace] Sombra appears. El Hombre recognizes the dimension of the afterlife (the awakening), which includes the recognition of the all-determining principle of the eternal (or: The Eternal) and the necessity to submit to this principle and to act according to its laws. He gets back Entendimiento and Albedrío, Albedrío being forcibly brought up by Entendimiento and laid at El Hombre's feet. El Hombre pleads with Poder for forgiveness. Sabiduría appears in human nature in the guise of a foreign wanderer and frees El Hombre from his chains, putting them on herself. Sombra and El Príncipe attack the prisoner, whom they mistake for El Hombre, with tree-branches, but fall down dead at the feet of Sabiduria/Christ on the cross. Finally, Agua supplies the element for baptism and each of the other Elements supplies some part of what will become the Eucharist. In order to be able to act "in the dream of life" according to the "laws of the Eternal" so that the "awakening" will not occur in the "prison of Darkness," El Hombre is accompanied by Entendimiento, Albedrío and Luz/Gracia (The Light of Grace); through the ritual repetition in the sacrament of the Eucharist he can always again participate in the grace conferred on him by the divine self-sacrifice.

69 For the concept and terminology, see the article by Joachim Küpper in this volume. 
which ultimately also shows once more that this question was a problem that challenged thinkers from all over Europe in that era. The quest for certainty, the symptom of the time, so to speak, became more and more virulent particularly in the first half of the seventeenth century: ${ }^{70}$ Descartes' project is only the most conspicuous symptom of the attempt to overcome skepticism with the intention to establish a firm basis of certainty, of knowledge, a philosophical foundation for the scientific exploration of the world.

In both Hamlet and La vida es sueño the theatrical device of the play-withinthe-play is used to bring skepticism and the problems linked to it to the stage. The two dramas are not limited to merely staging the basic skeptical argument, but try to go further. The questions concerning epistemology are linked to the ethical dimension, raising fundamental questions of moral philosophy that the two plays approach and "answer," though in very different ways. In Calderón's treatment of skepticism, the focus is, ultimately, on religious didactics. In the sense of a "method" anticipating on a very abstract level the approach of Descartes, the doubt regarding sensory perception is exaggerated in La vida es sueño with the aim of preparing the recipients to accept the play's final argument committed to the Counter-Reformation project. From the perspective of the eternal world, the question of whether a distinction can be made between dream and reality is dismissed as irrelevant, in favour of the relevance of (ethical) action; the action has an effect, for better or for worse, in relation to the life in the world beyond. At the end of the comedia there is neither skeptical epoché, nor epistemology, but, rather, the certainty of religious dogma. In Hamlet, however, there is no "solution" provided for the problem posed by the basic skeptical argument; the play remains ambivalent in this regard. To that extent, it is an "open," modern text. Shakespeare does not raise the epistemological question from a dogmatic Christian standpoint, and he gave the material the form of a tragedy. As optimistic as the outcome is for the Polish prince presented in Calderón's drama, so disastrous is it for Shakespeare's Danish prince. In its consequences, skepticism, as it comes to be represented in Hamlet, is destructive. The ancient skeptics' "promise" of tranquil epoché (which is endorsed, for instance, by the serene humanism of Montaigne) is depotentiated and becomes substituted by despair. It is ultimately not possible to abdicate from sure knowledge of what is-in this way, Shakespeare's play certainly does not present any solutions; but it clearly formulates a desideratum, without, however, pointing out the direction where its fulfilment may be found.

70 See Popkin, History of Scepticism, esp. pp. 97-99. 